\title{
Development Status for a Combined Solid Oxide Co- Electrolyzer and Carbon Formation Reactor System for Oxygen Regeneration
}

\author{
Robert D. Green ${ }^{1}$ \\ NASA Glenn Research Center, Cleveland, OH, 44135, USA \\ Paul H. Matter ${ }^{2}$, Chris Holt ${ }^{3}$, Michael Beachy ${ }^{4}$, James Gaydos ${ }^{5}$, \\ pHMatter LLC, Columbus, OH, 43212, USA \\ Serene C. Farmer ${ }^{6}$ and John Setlock ${ }^{7}$ \\ NASA Glenn Research Center, Cleveland, OH, 44135, USA
}

\begin{abstract}
A critical component in spacecraft life support loop closure is the removal of carbon dioxide $\left(\mathrm{CO}_{2}\right.$, produced by the crew) from the cabin atmosphere and chemical reduction of this $\mathrm{CO}_{2}$ to recover the oxygen. In 2015, we initiated development of an oxygen recovery system for life support applications consisting of a solid oxide co-electrolyzer (SOCE) and a carbon formation reactor (CFR). The SOCE electrolyzes a combined stream of carbon dioxide $\left(\mathrm{CO}_{2}\right)$ and water $\left(\mathrm{H}_{2} \mathrm{O}\right)$ gas mixtures to produce synthesis gas (e.g., $\mathrm{CO}$ and $\mathrm{H}_{2}$ gas) and pure dry oxygen as separate products. This SOCE is being developed from a NASA GRC solid oxide fuel cell and stack design originally developed for aeronautics longduration power applications. The CFR, being developed by pHMatter LLC, takes the CO and $\mathrm{H}_{2}$ output from the SOCE, and converts it primarily to solid carbon $\left(\mathrm{C}_{(\mathrm{s})}\right)$ and $\mathrm{H}_{2} \mathrm{O}$ and $\mathrm{CO}_{2}$. Although the solid carbon accumulates in the CFR, the innovative design allows easy removal of the carbon product, requiring minimal crew member (CM) time and low resupply mass $(1.0 \mathrm{~kg} / \mathrm{year} / \mathrm{CM})$ for replacement of the solid carbon catalyst, a significant improvement over previous Bosch reactor approaches. In this work, we will provide a status of our Phase I efforts in the development and testing of both the SOCE and CFR prototype units, along with an initial assessment of the combined SOCE-CFR system, including a mass and power projections, along with an estimate of the oxygen recovery rate.
\end{abstract}

\section{Nomenclature}

$\begin{array}{ll}B O P & =\text { Balance-of-Plant } \\ C D R A & =\text { Carbon Dioxide Removal Assembly } \\ C F R & =\text { Carbon Formation Reactor } \\ C M & =\text { Crew Member } \\ C R S & =\text { Carbon dioxide Reduction System } \\ E D S & =\text { Energy Dispersive Spectroscopy } \\ G D C & =\text { Gadolinia Doped Ceria }\end{array}$

${ }^{1}$ Aerospace Engineer, Fluid Physics and Transport Branch, 21000 Brookpark Rd., MS 77-5, AIAA non-member.

${ }^{2}$ President/Founder, pHMatter LLC, 1275 Kinnear Rd, AIAA non-member.

${ }^{3}$ Vice President, pHMatter LLC, 1275 Kinnear Rd, AIAA non-member.

${ }^{4}$ Senior Chemical Engineer, pHMatter LLC, 1275 Kinnear Rd, AIAA non-member.

${ }^{5}$ Mechanical Engineer, pHMatter LLC, 1275 Kinnear Rd, AIAA non-member.

${ }^{6}$ Materials Research Engineer, Materials Chemistry and Physics Branch, 21000 Brookpark Rd., Mail Stop 106-1, AIAA non-member.

${ }^{7}$ Senior Research Associate, Environmental Effects and Coatings Branch, 21000 Brookpark Rd., Mail Stop 106-1, AIAA non-member. 


$\begin{array}{ll}\text { JSC } & =\text { Johnson Space Center } \\ M S F C & =\text { Marshall Space Flight Center } \\ O G A & =\text { Oxygen Generation Assembly } \\ P P A & =\text { Plasma Pyrolysis Assembly } \\ R W G S & =\text { Reverse Water Gas Shift reaction } \\ \text { SOCE } & =\text { Solid Oxide Co-Electrolyzer } \\ W G S & =\text { Water Gas Shift reaction } \\ Y S Z & =\text { Yttria-Stablilized Zirconia }\end{array}$

\section{Introduction}

$\mathrm{N}$ ASA has called for improved process technologies for life support loop closure to enable extended manned exploration missions beyond Earth's atmosphere. A critical component in life support loop closure is the removal of carbon dioxide $\left(\mathrm{CO}_{2}\right.$, produced by the crew) from the cabin atmosphere and chemical reduction of this $\mathrm{CO}_{2}$ to recover the oxygen. Currently, the Carbon dioxide Reduction System (CRS) on the ISS utilizes the Sabatier process as the method of $\mathrm{CO}_{2}$ reduction. In this reaction, the $\mathrm{CO}_{2}$ is reduced with hydrogen to form the products, methane $\left(\mathrm{CH}_{4}\right)$ and water. The water is electrolyzed via the Oxygen Generation Assembly (OGA) to complete oxygen recovery; the $\mathrm{CH}_{4}$ is vented overboard. The Sabatier process results in an overall theoretical oxygen recovery rate of $50 \%$, as the loss of 2 moles of $\mathrm{H}_{2}$ for every mole of $\mathrm{CH}_{4}$ vented requires a resupply of hydrogen (or water). This translates to a significant supply of hydrogen being required at the start of a mission; approximately 33 $\mathrm{kg}$ of hydrogen per person per year, or $298 \mathrm{~kg}$ of water. The oxygen recovery rate can be increased by reducing the $\mathrm{CH}_{4}$ product to higher $\mathrm{C}: \mathrm{H}$ ratio hydrocarbons, and in fact, a Plasma Pyrolysis Assembly (PPA), developed by UMPQUA Research Company converts $\mathrm{CH}_{4}$ via plasma pyrolysis to acetlylene $\left(\mathrm{C}_{2} \mathrm{H}_{2}\right)$, and has been successfully been tested at NASA MSFC, and has achieved a $\mathrm{CH}_{4}$ to $\mathrm{C}_{2} \mathrm{H}_{2}$ conversion of $90 \% ;{ }^{1,2}$ at this conversion rate, this technology, in combination with the CRS, can achieve $\sim 78 \%$ oxygen recovery rate from a $\mathrm{CO}_{2}$ feed stream.

In order to achieved even higher oxygen recovery rates, $\mathrm{CO}_{2}$ must be reduced further to solid carbon. In this paper, we discuss our initial Phase I development of a two stage water and carbon dioxide reduction system that consists of a solid oxide co-electrolyzer (SOCE) and carbon formation reactor (CFR) that will enable a nearly $90 \%$ oxygen recovery rate while minimizing power, resupply mass/volume, crew time

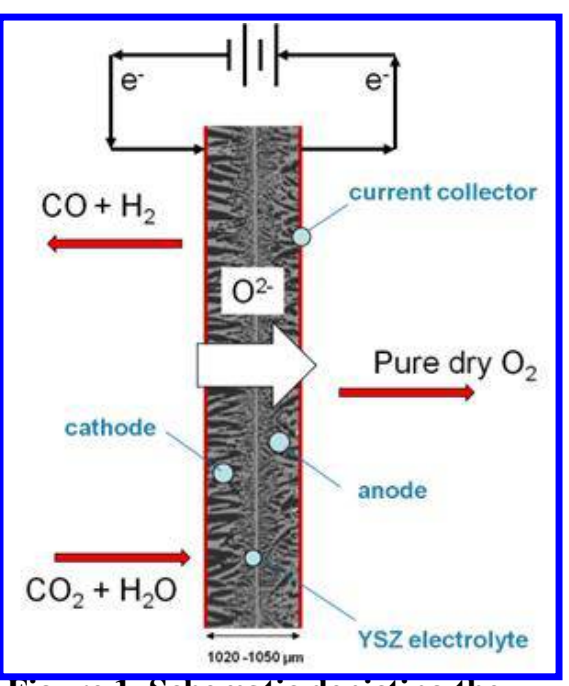

Figure 1. Schematic depicting the basic operation of a solid oxide coelectrolysis device. Optical image of Bi-Supported Cell(BSC) developed by NASA GRC is shown. requirements, and functionally replace both the CRS and OGA.

\section{A. Basic Operation of the Solid Oxide Co-Electrolyzer (SOCE)}

A single solid oxide co-electrolyzer (SOCE) cell consists of a yttria-stabilized zirconia (YSZ) membrane sandwiched between two electrode layers as shown in Fig. 1. A potential of 1-2 V is applied (per cell), and gaseous $\mathrm{CO}_{2}$ and $\mathrm{H}_{2} \mathrm{O}$ are fed to the cathode side, where the following reactions occur at a typical operating temperature of $800-850{ }^{\circ} \mathrm{C}$ :

$$
\begin{aligned}
& \mathrm{CO}_{2} \text { is dissociates to } \mathrm{CO} \text { and oxygen ions }\left(\mathrm{O}^{2-}\right) \\
& \qquad \mathrm{CO}_{2}+2 \mathrm{e}^{-} \rightarrow \mathrm{CO}+\mathrm{O}^{2-} \\
& \text { and } \mathrm{H}_{2} \mathrm{O} \text { dissociates into } \mathrm{H}_{2} \text { and } \mathrm{O}^{2-} \\
& \mathrm{H}_{2} \mathrm{O}+2 \mathrm{e}^{-} \rightarrow \mathrm{H}_{2}+\mathrm{O}^{2-}
\end{aligned}
$$

For both of the above reactions, the $\mathrm{O}^{2-}$ ions transport across the zirconia electrolyte and recombine to form pure oxygen on the anode side: 


$$
2 \mathrm{O}^{2-} \rightarrow \mathrm{O}_{2}+4 \mathrm{e}^{-}
$$

As YSZ will conduct only oxygen ions, this process produces essentially pure dry oxygen — an advantage in life support systems - since no further processing is needed to remove unconverted chemical species or excess water, allowing for easier humidity control. Also, because of the high temperature, both product streams are sterile, eliminating bacterial or other biogrowth concerns over long-term operation. Electrode catalysts are tailored to the electrochemical reactions. For $\mathrm{CO}_{2}$ or $\mathrm{H}_{2} \mathrm{O}$ electrolysis, the electrode catalyst is a composite or cermet such as Ni-YSZ or $\mathrm{Ni}$-ceria. Typical anodes for the oxygen recombination reaction (Eq. (3)) are lanthanum strontium cobalt ferrite (LSCF) or lanthanum strontium manganite (LSM).

Although the theoretical minimum power to electrolyze $\mathrm{CO}_{2}$ is approximately the same as for the electrolysis of $\mathrm{H}_{2} \mathrm{O}$ for the same $\mathrm{O}_{2}$ production rate $\left(293.0 \mathrm{~kJ} / \mathrm{mol}\right.$ vs. $285.9 \mathrm{~kJ} / \mathrm{mol}$ of $\left.\mathrm{O}_{2}\right)$, the voltage potential to electrolyze $\mathrm{CO}_{2}$ is higher than for $\mathrm{H}_{2} \mathrm{O}$, and the $\mathrm{CO}_{2}$ electrochemical reduction kinetics tend to be slower. For these reasons, it is believed that $\mathrm{CO}_{2}$ conversion is primarily due to the reverse water gas shift reaction (RWGS) occurring as a heterogeneous reaction in the cathode side of the SOCE: ${ }^{3}$

$$
\mathrm{CO}_{2}+\mathrm{H}_{2} \rightarrow \mathrm{CO}+\mathrm{H}_{2} \mathrm{O}
$$

The SOCE performs like a RWGS reactor and $\mathrm{H}_{2} \mathrm{O}$ electrolyzer in a single device and has the potential to increase conversion of $\mathrm{CO}_{2}$ to $\mathrm{CO}$ for two reasons. It operates at significantly higher temperatures $\left(800-900{ }^{\circ} \mathrm{C}\right)$ which allows the equilibrium point for Equation (4) to shift to the right corresponding to a higher equilibrium conversion. In addition, as $\mathrm{H}_{2} \mathrm{O}$ is electrolyzed and $\mathrm{O}_{2}$ is removed from the cathode side, the $\mathrm{H}_{2} \mathrm{O}$ concentration decreases (and corresponding $\mathrm{H}_{2}$ concentration increases), allowing shift of the equilibrium point for Equation (4) further to the right.

Lastly, an SOCE integrated into the air revitalization system can potentially eliminate a separate $\mathrm{H}_{2} \mathrm{O}$ (only) electrolyzer and save extra system mass/volume.

\section{B. Basic operation of the Carbon Formation Reactor (CFR)}

Carbon dioxide $\left(\mathrm{CO}_{2}\right)$ and carbon monoxide $(\mathrm{CO})$ can be reduced to solid elemental carbon in a Carbon Formation Reactor (CFR) via the Bosch or Boudouard reactions:

(Bosch reaction)

(Boudouard reaction)

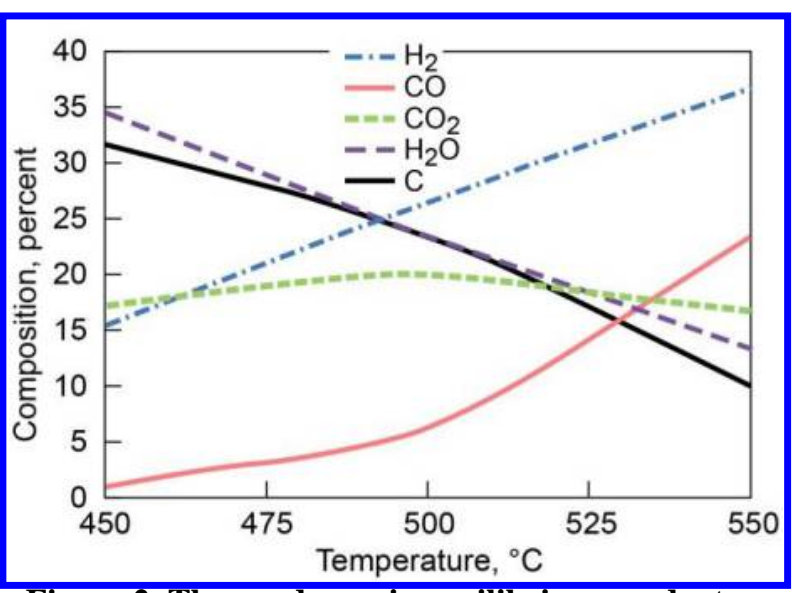

Figure 2. Thermodynamic equilibrium product composition as a function of temperature at atmospheric pressure for a CFR downstream of SOCE in a single pass system. Calculations assume Boudouard, Bosch, and WGS equilibrium.

$$
\begin{aligned}
& \mathrm{CO}_{2(\mathrm{~g})}+2 \mathrm{H}_{2(\mathrm{~g})} \rightarrow \mathrm{C}_{(\mathrm{s})}+2 \mathrm{H}_{2} \mathrm{O}_{(\mathrm{g})} \\
& 2 \mathrm{CO}_{(\mathrm{g})} \rightarrow \mathrm{C}_{(\mathrm{s})}+\mathrm{CO}_{2(\mathrm{~g})}
\end{aligned}
$$

The thermodynamic equilibrium products, assuming operation on an SOCE exhaust as the feed and equilibrium for the water-gas shift (WGS) reaction, are shown in Figure 2. Complete conversion and selectivity to carbon is not thermodynamically possible, but higher carbon formation is favored at lower temperatures, with nearly $60 \%$ solid carbon yield (on a carbon basis) possible. Unreacted gaseous products can be recycled to ultimately convert nearly all of the $\mathrm{CO}_{2}$ into carbon. Although carbon formation is thermodynamically favored at lower temperatures, the kinetics for carbon formation are slower, therefore a catalyst must be used in the CFR. A good catalyst is both active for carbon formation and has low selectivity to methane formation via the Sabatier reaction. Although, methane formation will ultimately be limited by equilibrium, significant methane gas composition will increase the recycle stream and potentially be a source of coking (carbon deposition) in other components of the system, such as the SOCE.

\section{Advantages of a 2-stage SOCE-CFR oxygen recovery system.}

By integrating the SOCE and CFR technologies, $\mathrm{CO}_{2}$ can be converted to oxygen and solid carbon in a low complexity two-stage chemical process has the potential to achieve a high oxygen recovery rate. $\mathrm{CO}_{2}$ conversion 
rates for the Bosch reactor alone is $\sim 8 \%-10 \%{ }^{4}$ By first partially reducing the $\mathrm{CO}_{2}$ to $\mathrm{CO}$ in a SOCE, the Bosch reaction can be separated to improve single (first-pass) conversion. We estimate we can achieve $80 \%$ conversion of both $\mathrm{CO}_{2}$ and $\mathrm{H}_{2} \mathrm{O}$ in a single pass through the SOCE. The CFR, with this high concentration of $\mathrm{CO}$ and $\mathrm{H}_{2}$ as input, has a much improved conversion efficiency, and as such, an overall single-pass oxygen recovery recovery of $70 \%$ can be achieved in the 2-stage system. By recycling the CFR exit gas stream, the theoretical oxygen recovery is $100 \%$, but we will show that taking into account the need to purge expected gas build-up, etc. an oxygen recovery rate of nearly $90 \%$ can be achieved.

\section{Solid Oxide Co-Electrolyzer (SOCE) Development}

\section{A. SOCE cell stack design}

The specific power for state-of-the-art (SOA) solid oxide fuel cells (SOFCs), being developed for terrestrial stationary and portable power applications, is $\sim 0.3 \mathrm{~kW} / \mathrm{kg}$. For aerospace applications, NASA Glenn Research Center (GRC) has developed a patented cell and stack with the potential to achieve a 3 to 4 times increase in power density. This is accomplished by eliminating metal interconnects and frames, which are up to $70 \%$ of the stack mass, and replacing them with a thin ceramic membrane with the gas channels moved into the electrodes. The cell design is called a bi-electrode supported cell (BSC) because it is structurally symmetrical and has identical gas channels on the oxidant and fuel sides. The BSC stack design is a cross-flow design; that is, the cathode and anode gas pathways are $90^{\circ}$ opposed to one another. The BSC cell layers are assembled into a stack configuration (cells connected in series) in a "green" (unfired) state. Glass-ceramic seals are then applied as a glass liquid to alternating layer on each side to block off opposing gas paths, and the entire stack is sintered at high temperature $\left(1550{ }^{\circ} \mathrm{C}\right)$ to form a rigid "monolithic block."

Figure 3 displays a diagram of 2 cells with the seal configuration to achieve this cross-flow design, along with photo of an actual fabricated 3-cell stack with gas manifolds installed. This 3-cell stack consists of 5.0- x 5.0-cmarea cells, with the total height of a 3-cell stack being $0.4 \mathrm{~cm}$, including the interconnect layers, which provide electronic conduction between cells. Mass of the stack alone is $36 \mathrm{~g}$; the 3-cell stack shown in the figure, including the gas manifolds has a total mass of $68.2 \mathrm{~g}$.
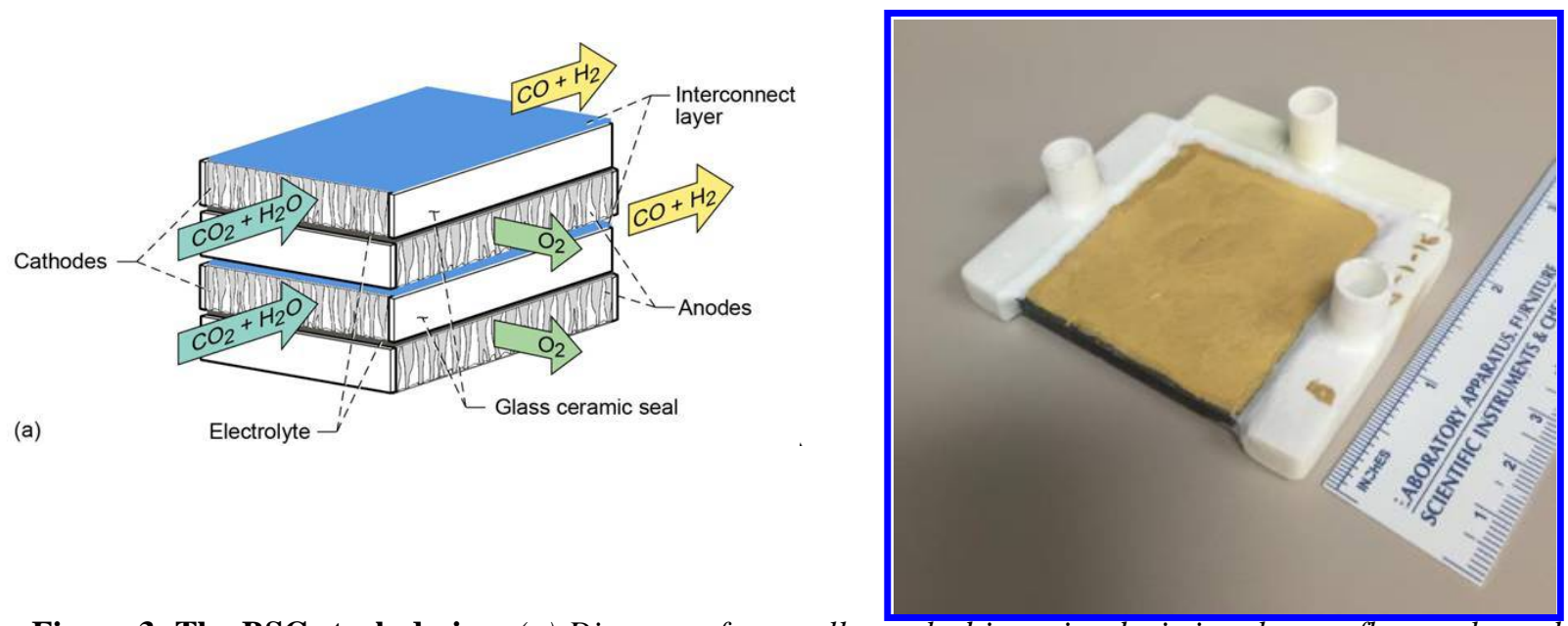

Figure 3. The BSC stack design. (a) Diagram of two cells stacked in series depicting the gas flow paths and sealing configuration in a cross-flow stack design. (b) Photograph of a fabricated 3-cell stack with gas manifolds installed for testing.

\section{B. SOCE single cell testing}

Our baseline cathode for co-electrolysis is a Nickel-Samaria Doped Ceria (Ni-SDC) deposited on a variable porosity YSZ scaffold structure. As part of the early portion of this project, we initiated an effort to evaluate an advanced cathode for solid oxide co-electrolysis, primarily due to concerns that the state-of-the-art cathode, Ni-YSZ (Ni-Yttria-Stabilized Zirconia) cermet, is susceptible to oxidation under pure $\mathrm{CO}_{2}$ and/or pure water (steam) conditions, which can occur in our proposed SOCE-CFR system during or off-nominal conditions i.e. start-up, shutdown, etc. Recent work has focused on gadolinia doped ceria (GDC) for both $\mathrm{H}_{2} \mathrm{O}$ and $\mathrm{CO}_{2}$ reduction, ${ }^{5-7}$ in that it is a mixed conductor and potentially a good heterogeneous catalyst; ceria is used as a catalyst support (with finely dispersed noble metals $\mathrm{Pt}$ and $\mathrm{Rh}$ ) for oxidation of carbon monoxide and other hydrocarbons in automotive three- 
way catalytic converters due to its oxygen storage capacity. ${ }^{8}$ We chose a Pt-GDC for our advanced development $\mathrm{CO}_{2}$ reduction cathode, namely because of the expected oxidation tolerance of $\mathrm{Pt}$ compared to $\mathrm{Ni}$, and it's potential enhanced catalytic activity for $\mathrm{CO}_{2}$ reduction with GDC. Details on the cell fabrication and test setup will be described in a future publication. ${ }^{9}$

Figure 4 provides the resulting polarization scans of the baseline Ni-SDC baseline cathode cell vs. the Pt-GDC advanced development cathode cell. The results, comparing Figure 4 (a) with 4 (b), indicate the baseline Ni-SDC cathode did perform better (lower slope) than the Pt-GDC, but the Ni-SDC was tested (in 2008) under higher $\mathrm{H}_{2} \mathrm{O}$ : $\mathrm{H}_{2}$ ratios, namely 19:1 for Ni-SDC vs. 1:1 to $1: 5$ for the Pt-GDC. The lower $\mathrm{H}_{2} \mathrm{O}: \mathrm{H}_{2}$ conditions for the Pt-GDC cells reduce diffusion/mass transfer of the $\mathrm{H}_{2} \mathrm{O}$ reactant to the electrode/electrolyte interface, and result in higher cell voltages due to concentration overpotentials.

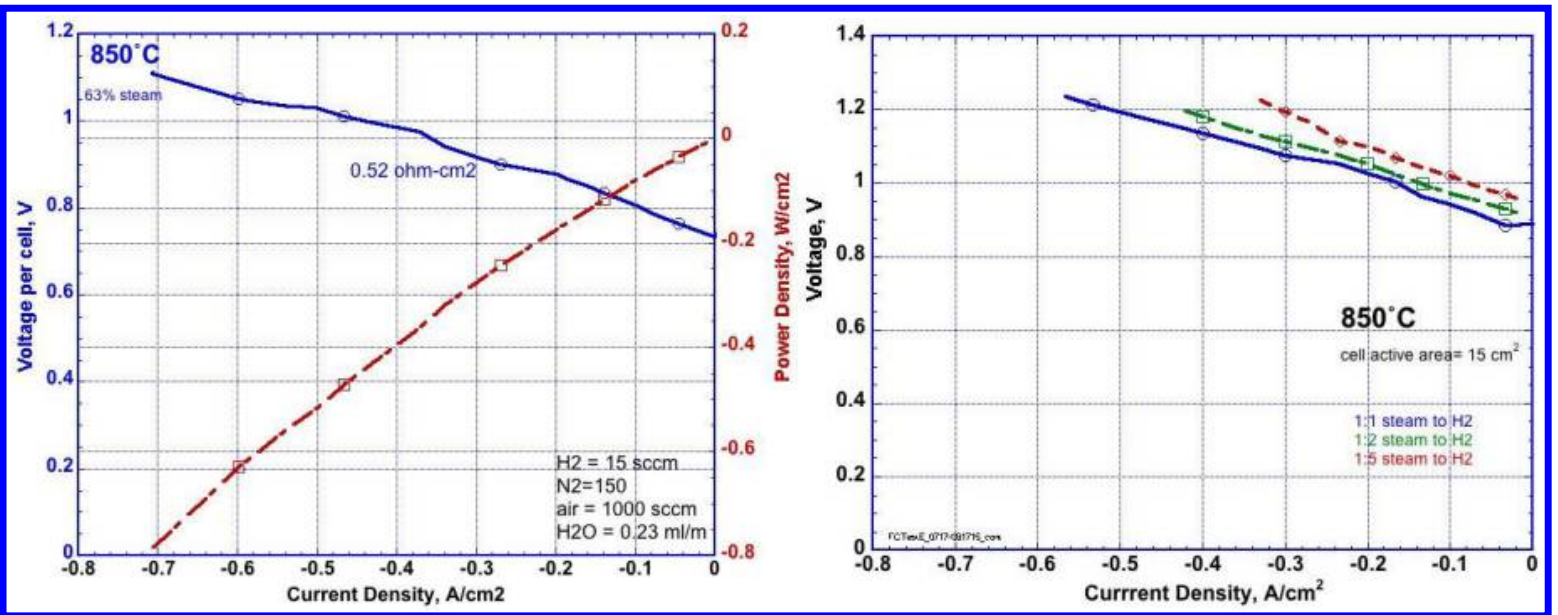

Figure 4. Single cell polarization (VI) scans in steam electrolysis. (a) Baseline Ni-SDC cathode single cell. (b) Advanced development Pt-GDC cathode single cell \#2.

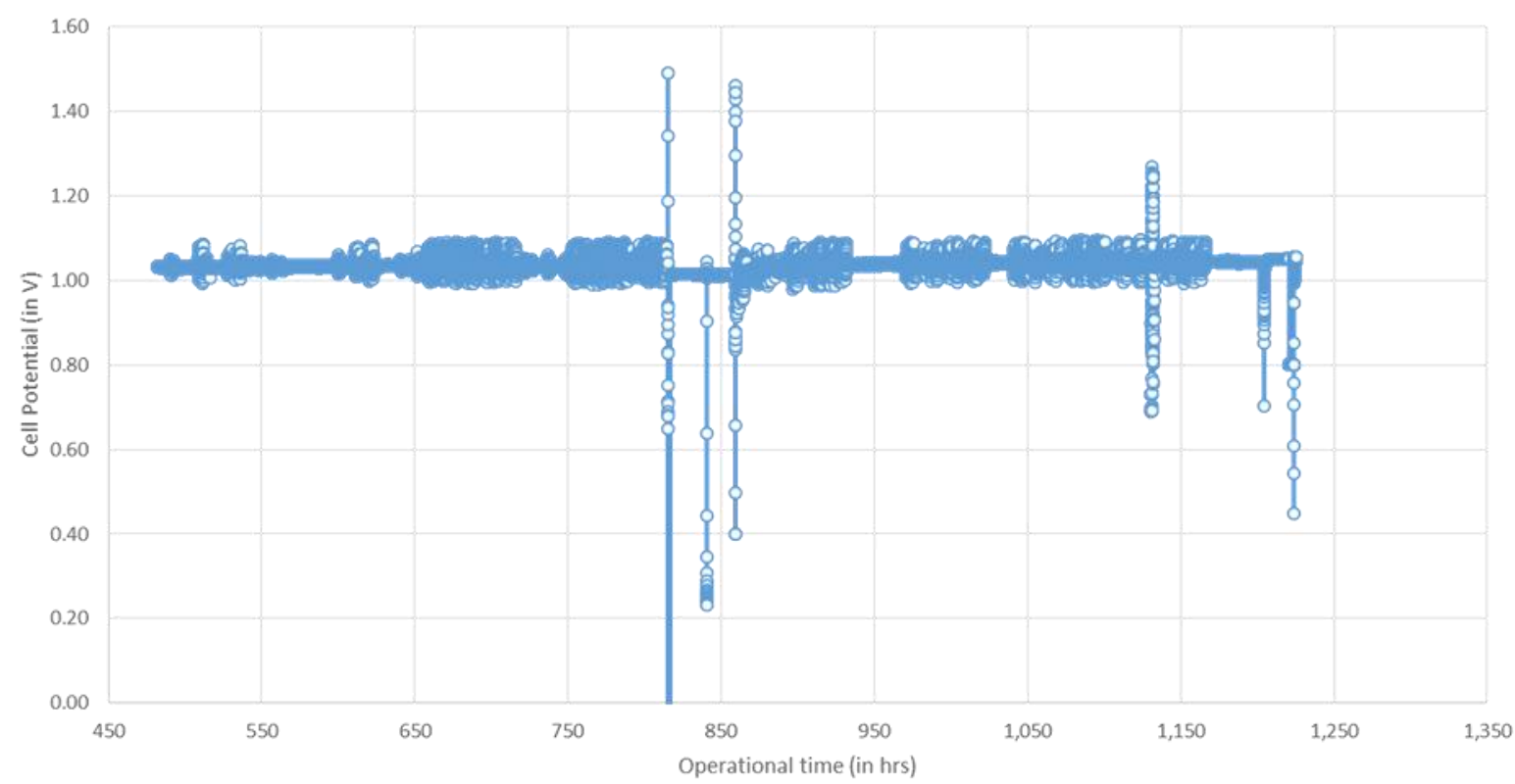

Figure 5. Durability 1200 hour test of Pt-GDC cell \#2. Cell was operated a constant current density of $0.2 \mathrm{~A} / \mathrm{cm}^{2}$. Large spikes and voltage drops were due to intermittent polarization scans and two facility power outages during the 2 months of testing. 
In addition, long duration testing was performed on Pt-GDC cathode single cells to evaluate degradation under constant current steam electrolysis conditions; testing was performed by operating at a constant current and measuring the increase in cell voltage. Degradation for Ni-SDC cathode cells in steam electrolysis testing performed in 2008-2009, had varied from 3-30\%. ${ }^{10}$ In the present work, two Pt-GDC cells were tested long-duration (> $500 \mathrm{hrs}$ ) under constant current conditions at our design current density of $0.2 \mathrm{~A} / \mathrm{cm}^{2}$. Pt-GDC Cell \#1 saw $3 \%$ degradation over 600 hours of operation. Pt-GDC Cell \#2 saw less than 1\% degradation after 1200 hours of operation. Figure 5 shows the cell voltage for Pt-GDC cell \#2 measured over the last 700 hours of the 1200 hour period. Although these results are preliminary and limited to just two single cells tested under steam-only conditions, Pt-GDC cathode cells do exhibit significantly lower degradation rates than the baseline Ni-SDC cathodes.

\section{SOCE stack development and testing}

For the Phase I effort, fabrication and demonstration of a 3-cell stack, as shown previously in Figure 3 (b), that is hermetically sealed was the main objective. The key feature of the BSC design is a structurally symmetrical cell, which is made by supporting the thin YSZ electrolyte on both sides with a porous YSZ support structure of equal thickness, thus the name bi-supported cell or BSC. This porous YSZ support structure (or scaffold), which serves as the electrode layer is an open structure with graded porosity. This enables the electrode scaffold itself to be used as the gas channels, albeit the backpressure of each cell is higher than in commercial cells where the gas channels are part of the metal interconnect.

In the current design, the electrolyte and electrode layer consists of 8 mole $\%$ yttria-stabilized zirconia (or $8 \mathrm{YSZ}$ ), and the interconnect layer is a co-doped lanthanum chromite, $\mathrm{La}_{1-\mathrm{x}} \mathrm{Ca}_{\mathrm{x}} \mathrm{Cr}_{1-\mathrm{y}} \mathrm{Co}_{\mathrm{y}} \mathrm{O}_{3-\partial}$. The electrolyte and interconnect layers are fabricated using tape casting, a conventional ceramic processing technique. The electrode scaffolding layer is fabricated using freeze-casting, to achieve the variable porosity through the electrode layer thickness. Triangular (or V-shaped) cross-section channels are laser-etched into the electrode layers to improve gas flow. After casting, all layers were cut to size using a laser plotter, assembled, and fired at $1550^{\circ} \mathrm{C}$. Figure 6 shows an image of a post-fired stack body with each of these layers corresponding to a single cell, highlighted.
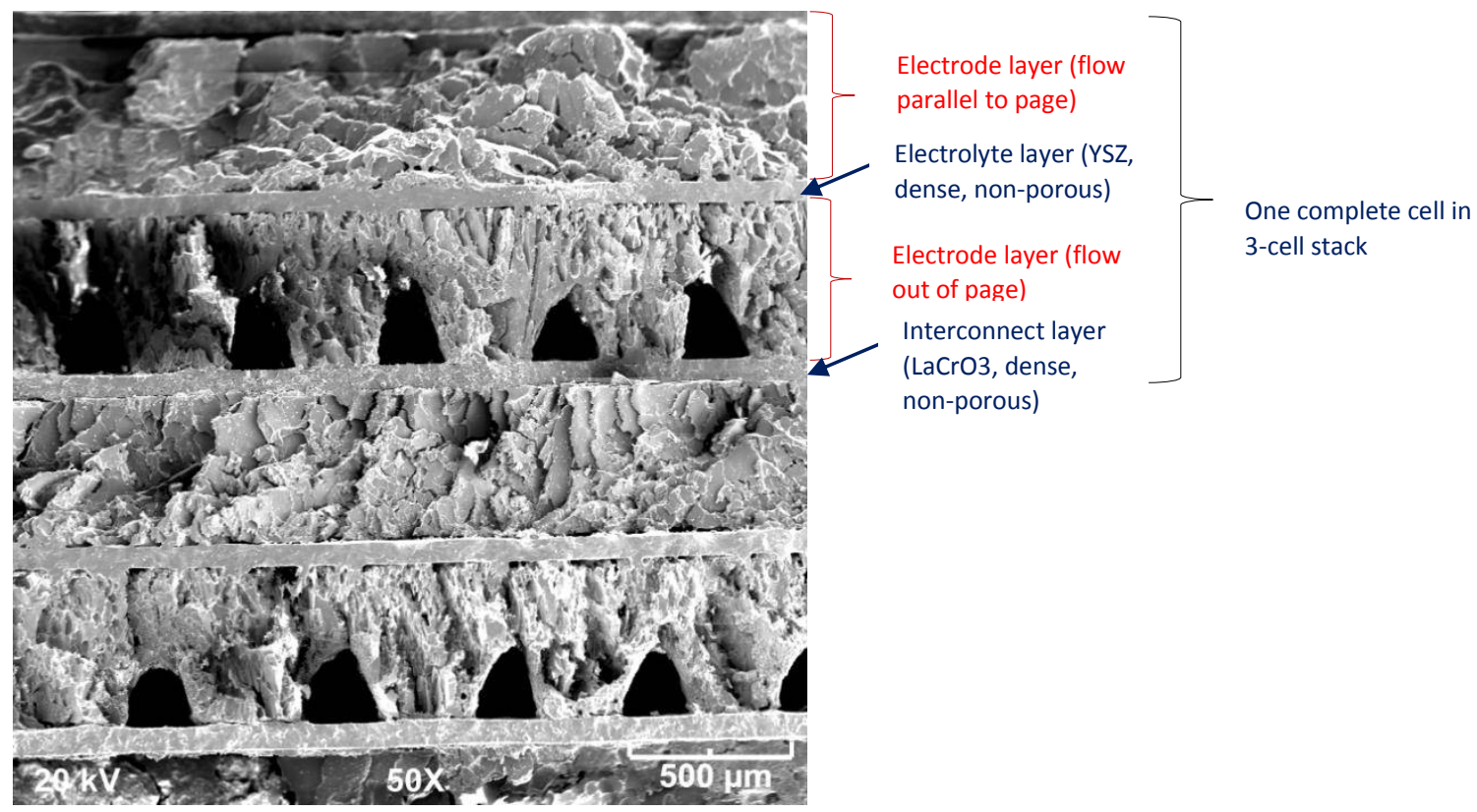

out of page)

Interconnect layer

(LaCrO3, dense,

non-porous)

3-cell stack

Figure 6. Scanning Electron Micrograph (SEM) image of a 3-cell stack body.

Once the stack body is made, alternate layers of the cross-flow design were sealed with a glass-ceramic. Sealing development was a large focus in the Phase 1 effort. We began this project using invert glass ceramic seal material; an invert glass differs from other glasses in their lower silica contents. We decided to work with invert glasses, as glasses of higher silica composition can form volatile SiOx species in the presence of moisture. In long-term durability testing in solid oxide steam electrolysis, deposition of silicates at the electrolyte interface was identified as one of several degradation mechanisms. Unfortunately, we had 2 compatibility issues with the invert glass 
formulation, namely "bloating" or cavity formation in the seals after sintering, and formation of an unknown reaction phase. After trying several blends of invert glass materials, this effort was abandoned and a conventional Si content glass-ceramic seal material was pursued. An ink, consisting of solvents, binder, and the glass powder was found to wet well and only a few trials were needed to seal stacks with no cracks visible in the optical microscope using alcohol as a penetrant. This same glass-ceramic was also successfully used to seal the manifolds to the stack body.

After sealing, the electrode scaffolds are then infiltrated with concentrated metal nitrate solutions to apply the electro-catalysts, GDC in the cathode layers and lanthanum chromite in the anode layers. The platinum in the cathode layers was infiltrated using chloroplatinic acid.

Although we solved the key sealing problem discussed above with a revised glass-ceramic material, our 3-cell stack testing was very limited due to leakage issues due to stack integrity, i.e. leakage between interconnect layers caused by internal stresses between layers during co-sintering of the stack which we were unable to completely solve during the later part of the project period. In addition, we observed severly current limited conditions during testing of 3-cell stacks, i.e. our current densities measured were low $\left(<0.1 \mathrm{~A} / \mathrm{cm}^{2}\right)$, compared to the $0.2 \mathrm{~A} / \mathrm{cm}^{2}$ projected design point that we performed our long duration single cell tests. We attribute this due to excessive reaction between the co-doped lanthanum chromite interconnect and the YSZ electrode scaffold layer. In post-test Energy Dispersive Spectroscopy (EDS) of 3-cell stack layers, we observed calcium rich zirconia extending beyond the initial point of contact with the interconnect, indicating possible formation of a passivation layer at the interconnect-electrode interface; loss of $\mathrm{Ca}$ from the interconnect layer also lowers its electronic conductivity An example polarization scan of one 3-cell stack is provided in Figure 7 under both $\mathrm{H}_{2} \mathrm{O}$ only and combined $\mathrm{H}_{2} \mathrm{O}$ and $\mathrm{CO}_{2}$ electrolysis. This data, although limited, appears to indicate that a portion of the $\mathrm{CO}_{2}$ is being electrolyzed (see eqn. 1), implying the RWGS reaction does not dominate the $\mathrm{CO}_{2}$ reduction in co-electrolysis, but it should be noted that the stack voltage was significantly above the thermo-neutral voltage for the electrochemical reduction of $\mathrm{CO}_{2}$ $\left(1.48 \mathrm{~V} /\right.$ cell at $\left.850^{\circ} \mathrm{C}\right)$, and the stack is operating under low $\mathrm{H}_{2} \mathrm{O}: \mathrm{H}_{2}$ conditions.

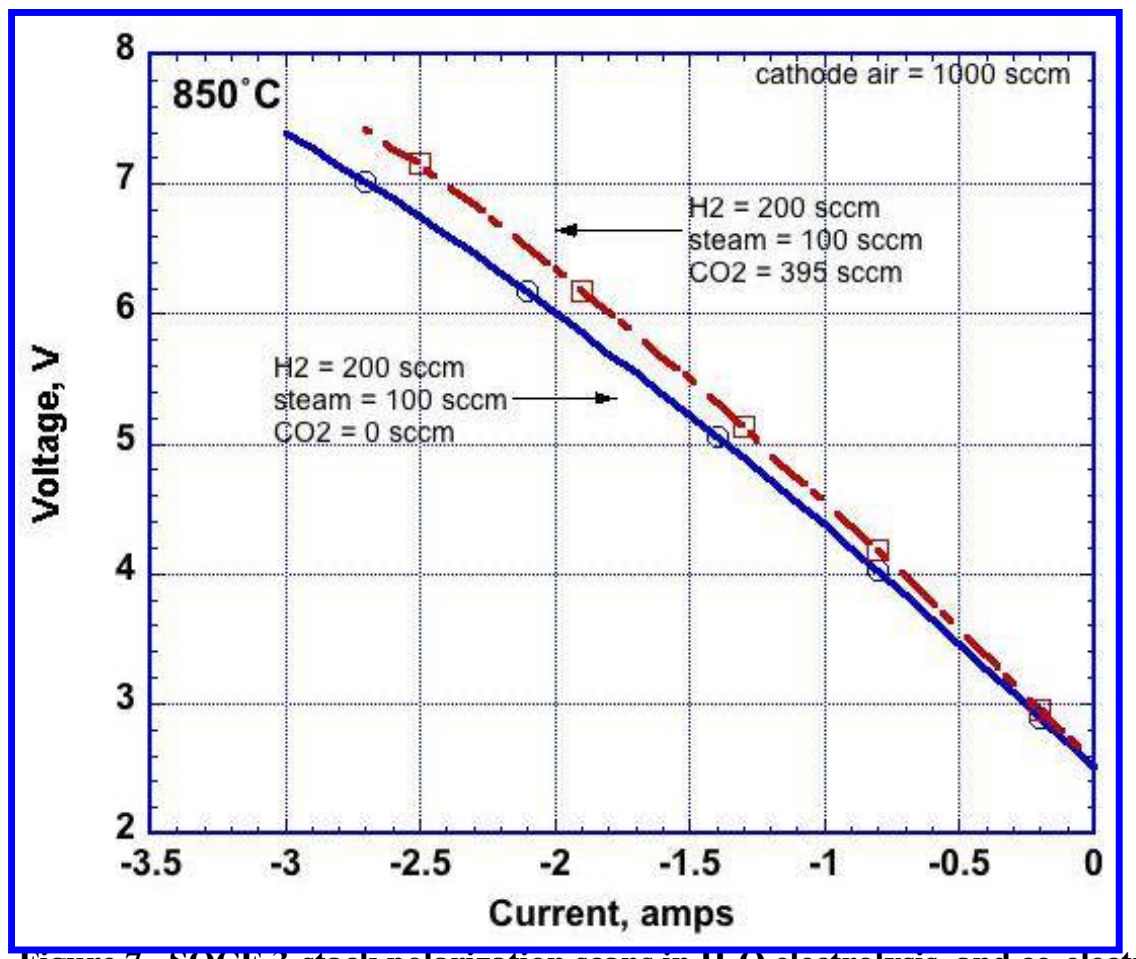

Figure 7. SOCE 3-stack polarization scans in $\mathrm{H}_{2} \mathrm{O}$ electrolysis, and co-electrolysis conditions. 


\section{Carbon Formation Reactor (CFR) Development}

The overall design goal of the CFR portion of this project was to demonstrate that a reactor based on a catalyst coatings approach could significantly reduce the size and mass of the CFR compared to previous CFR/Bosch reactor approaches, that in particular, require large resupply mass and volume requirements due to the need for frequent replacement of catalyst inserts or cartridges. ${ }^{11}$ The proposed resupply mass target for our CFR is less than 1 $\mathrm{kg} / \mathrm{year} / \mathrm{CM}$, based on catalyst development from a previous Phase I SBIR effort, with a catalyst regeneration and carbon removal frequency greater than 24 hours. The low resupply mass target, in particular, is a significant improvement over previous Bosch reactor designs. Based on engineering calculations for an initial 1-CM CFR design, it was determined that catalyst activity of at least $5.1 \mathrm{mg}_{\text {carbon }} / \mathrm{cm}^{2} / \mathrm{hr}$ was need to generate sufficient carbon for 1 -CM (272 g/day). Further based on this target of $5 \mathrm{mg} / \mathrm{cm}^{2} / \mathrm{hr}$ of catalyst loading, the catalyst must last at least 97 hours before replacement in order for the resupply mass to be $<1 \mathrm{~kg} / \mathrm{year}$. These calculations established the target for activity in the testing described in the following sections. Initial testing focused on catalyst coatings on woven carbon cloth. However, as will be discussed, testing eventually transitioned to catalyst coatings on steel surfaces, with carbon cloth used as a "filter" media at the reactor exit to retain the carbon and catalyst.

\section{A. CFR subscale reactor development and testing}

At the start of the project, a small scale $2.5-\mathrm{cm}$ OD reactor was set-up to test $5-\mathrm{cm}^{2}$ cloth discs mounted perpendicular to the gas flow. The purpose of this sub-scale reactor was to allow rapid testing of a range of catalyst, support, and feed conditions to determine the optimum parameters for the scaled-up CFR. This configuration was purposely designed to eliminate any mass transfer/flow uniformity issues. Tests were typically run overnight for 18 hours at temperature with a gas chromatograph measuring the dry product composition every 20 minutes. Over 35 tests were performed and key results included: Higher flow rates gave better activity at the expense of conversion (a range of 3-50 sccm flow rates were examined). An operating temperature $475^{\circ} \mathrm{C}$ was the optimal temperature for carbon generation rate and yield. The best-performing Fe-based catalysts do have some methane selectivity. As we noted in the Introduction section, there is a concern that carbon deposition due to methane could occur in the SOCE, it is likely that methane would not build up in a recycle loop because its product composition is equilibrium limited to fairly low concentrations $(<10 \%)$. The product gas composition remained stable once the operating temperature was reached and the product gas cleared out the downstream part of the system. This indicates that the growth rate is not aided by initial high activity, and can continue to produce carbon for a longer time. The catalyst can be supported either directly on the carbon cloth, or on cloth that is coated with carbon nanofibers. A carbon yield of $15-17 \%$ was repeatedly obtained under standard test conditions at the target growth rate. A higher carbon yield of $30.3 \%$ was obtained at the lowest flow rate, but the carbon generation rate was lower than our target rate for this condition.

After using the 2.5-cm OD CFR to focus on operating conditions and an improved sprayable Fe-based catalyst composition, a $7.5-\mathrm{cm}$ OD CFR test bed was constructed to test 3-dimensional catalyst supports. Three catalyst support configurations were used for this testing: (1) carbon bags with a fixed collar, (2) carbon bags strapped to the outside of an inlet tube, and (3) flat stainless steel sheets. The removable copper collar, which is sealed to the wall with an alumina fiber gasket, allowed the cloth to be easily removed and weighed after tests. The collar and carbon cloth were loaded into a $7.5 \mathrm{~cm}$ diameter quartz furnace, and fed using the same system used for $2.5 \mathrm{~cm}$ reactor testing. To test the stainless steel substrate as a catalyst support, flat $100-\mathrm{cm}^{2}$ sheets coated with catalyst were placed in the $7.5 \mathrm{~cm}$ reactor in an orientation perpendicular to the gas flow. To test carbon removal, the tests were interrupted to remove the support, cleaned by gentle brushing, and re-loaded in the reactor. The results of $7.5 \mathrm{~cm}$ sub-scale CFR determined that a 3:2 length-diameter dimension ratio for the cloth bag improved performance, and high carbon high activity could be obtained with either painting or spraying of the catalyst coating. The flat steel stainless steel sheets performed as well as both the carbon or steel cloth bags. This result became important as during this scaled-up $7.5 \mathrm{~cm}$ testing, it was found that both the carbon and steel cloth supports exhibited mechanical durability issues after 1 or several regeneration cycles. The stainless steel sheets correspondingly showed no durability issues, and subsequently was incorporated into the $15 \mathrm{~cm}$ OD reactor designs discussed in the next section. 


\section{B. CFR Alpha- and Beta-Prototype design and testing}

The "alpha-prototype" CFR test bed was initially designed and used to demonstrate activity and regeneration of $0.5 \mathrm{CM}$ scale carbon cloth catalyst supports. In this approach, carbon cloths were fixed inside a $15 \mathrm{~cm}$ OD

cylindrical reactor using retainer rings. In addition, after the initial promising results with steel sheets in the $7.5-\mathrm{cm}$ reactor tests discussed in the previous section, catalyst-coated stainless steel sheet reactor liners (with and uncoated carbon cloth covering the CFR gas exit) were also examined. The top of the reactor was clamped shut using three $90^{\circ}$ angle clamps that compress a graphite gasket between the lid and a lip on the reactor. The reactor was housed in a vertically-mounted clam shell furnace, and an insulation cap was placed over the top of the reactor and the clamps. Gas entered through the top-side of the cylinder, and exited (after passing the cloth) out the bottom-center of the cylinder. The steel sheets lining the reactor (with a carbon cloth disk covering the exit) held up better mechanically during long-term operation and through regeneration; no loss of catalyst activity was observed compared to carbon cloth in this configuration The sprayable Fe-based catalyst developed during the $2.5 \mathrm{~cm}$ CFR testing was demonstrated to meet resupply mass targets in the scaled-up $15 \mathrm{~cm}$ reactor design, and carbon activity above the target over 100 hours of operation was demonstrated. Finally, the carbon product generated in the reactor was soft and can be removed via vacuum methods.

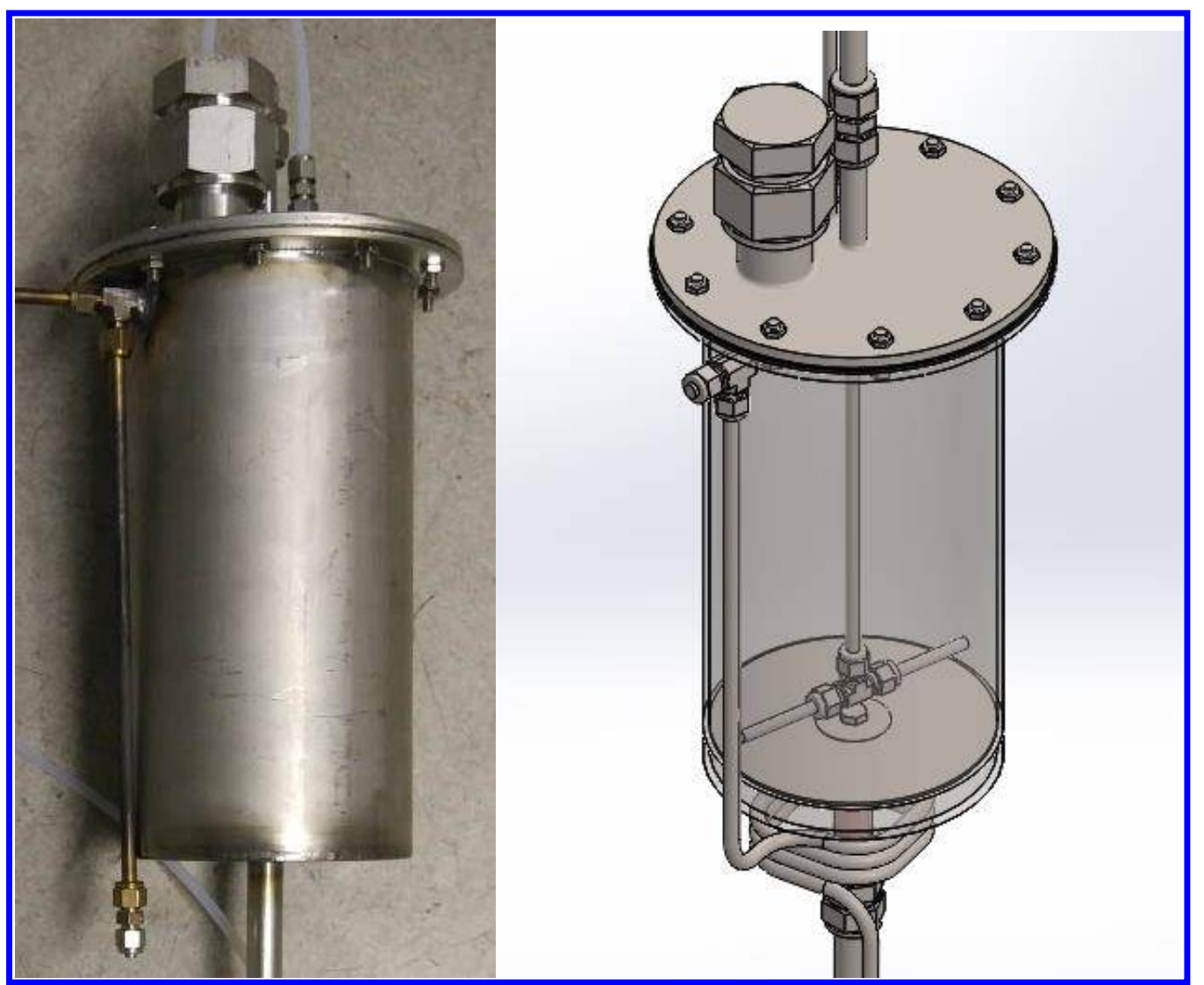

Figure 8. Beta-prototype CFR. (a) Photo image of Beta-Prototype CFR. (b) CAD drawing of interior of CFR showing agitator arm to break-up solid carbon. Large port on top of CFR is for carbon removal via vacuum.

Based on the results from alpha-prototype testing, a beta-prototype CFR/EDU was built for testing and eventual delivery. Figure 8 displays a photo and interior solid model drawing of the Beta-Prototype CFR design. The changes from the Alpha-Prototype CFR included a longer feed line (including coil) to pre-heat gases. A thermocouple was added to the gas inlet for monitoring inlet temperature. A port was added to the lid to allow an agitator arm to be inserted into the reactor, along with a 1.5" OD port vacuum carbon removal. A larger gas exit port was added with copper cladding to reduce risk of clogging due to carbon deposition favorable at the lower temperatures at the exit. Also, an improved bolted lid was included to reduce gas leakage. 
For the beta-prototype, spray-coated catalyst on stainless steel was utilized for all testing. For some tests, a stainless steel liner was initially spray-coated with catalyst, then loaded and activated in the reactor before the test began. In other cases, the CFR was activated by in situ spraying of the walls. The results of the Beta-Prototype CFR testing showed that activity targets were achieved over 100 hours with use of the spray regeneration. Pressure limits were reached after 130 hours with no agitation during test, and 144 hours of testing was demonstrated with periodic agitation and pressure did not increase. As high as 99\% carbon removal through vacuum port was demonstrated with use of an agitator, and typically $>97 \%$ of the carbon was removed. Performance and regeneration was also demonstrated with catalyst coating directly on the CFR wall (i.e. without the stainless steel liner).

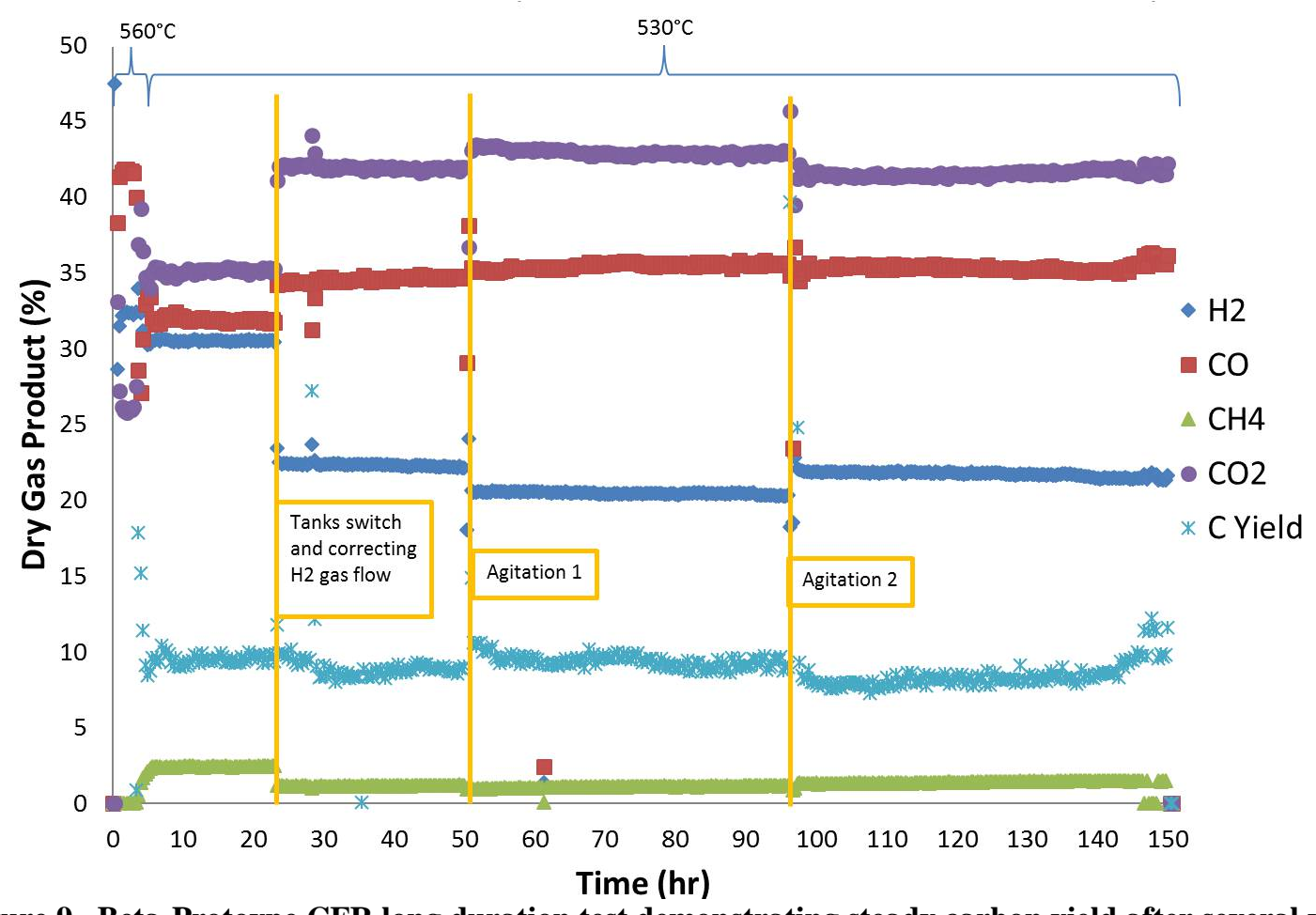

Figure 9. Beta-Protoype CFR long duration test demonstrating steady carbon yield after several vacuum carbon removal operations. CFR feed conditions were at a constant flow rate of 2200 sccm with a gas composition of $41 \% \mathrm{CO}, 33 \% \mathrm{CO}_{2}, 18 \% \mathrm{H}_{2}, 5 \% \mathrm{~N}_{2}, 3 \% \mathrm{H}_{2} \mathrm{O}$.

Figure 9 shows the results of a long-term test run with the Beta-Prototype CFR using an inlet gas composition based on our integrated CFR-SOCE system projections. The composition used was $41 \% \mathrm{CO}, 18 \% \mathrm{H}_{2}, 33 \% \mathrm{CO}_{2}, 3 \%$ $\mathrm{H}_{2} \mathrm{O}$, and 5\% $\mathrm{N}_{2}$. As shown in Figure 9, the test ran for 144 hours with steady carbon yield measured throughout the test. With the water and higher $\mathrm{CO}_{2}: \mathrm{CO}$ ratio in the feed, performance was lower than expected; however, the test did demonstrate stable carbon yield after several agitation cycles and vacuum carbon removal for the longest duration run for the project. With the periodic agitation of the reactor, the pressure drop did not increase during the test. The methane yield with the new composition was much lower than previous tests (about 1.4\%). This test demonstrated that the reactor can run for over 100 hours with periodic agitation, but more area or higher flows may be needed to meet carbon yield targets if the inlet feed has a high $\mathrm{CO}_{2}: \mathrm{CO}$ ratio.

\section{Projected Metrics for a 4-CM SOCE-CFR System}

\section{A. Preliminary system concept for a 4-CM scale SOCE-CFR oxygen recovery system.}

Figure 10 provides the overall mass balance for the 4-CM size SOCE-CFR system based on the crew metabolic loads provided in NASA/TP-2015-218570. ${ }^{12}$ For this, both the SOCE and CFR are pictorially represented as "lumped" units of 4-CM size; our preliminary design consists of 4 1-CM SOCE units and 4 1-CM scale CFR units in parallel to increase reliability and allow one CFR to be taken off-line for regeneration. The input and output rates are given in gas volumetric flow rate quantities at STP conditions. The $\mathrm{CO}_{2}$ input stream is assumed to contain 2 
vol\% $\mathrm{N}_{2}$ based on the ISS Carbon Dioxide Removal Assembly (CDRA) performance. The SOCE-CFR system would operate at sub-ambient pressures in order to eliminate the leakage of hazardous gases $\left(\mathrm{CO}, \mathrm{CO}_{2}\right.$, and $\left.\mathrm{H}_{2}\right)$ into the cabin atmosphere; the red dotted section depicted in Figure 10 represents the portion of the system that would operate at this sub-ambient condition. Both the hydrogen separator and purge streams are assumed to dump to a low pressure sink, i.e. near vacuum conditions expected external to the crew habitat whether for an in-transit mission or on a planetary surface mission. The SOCE can electrochemically "pump" the generated oxygen to ambient pressure in order to deliver to the crew environment.

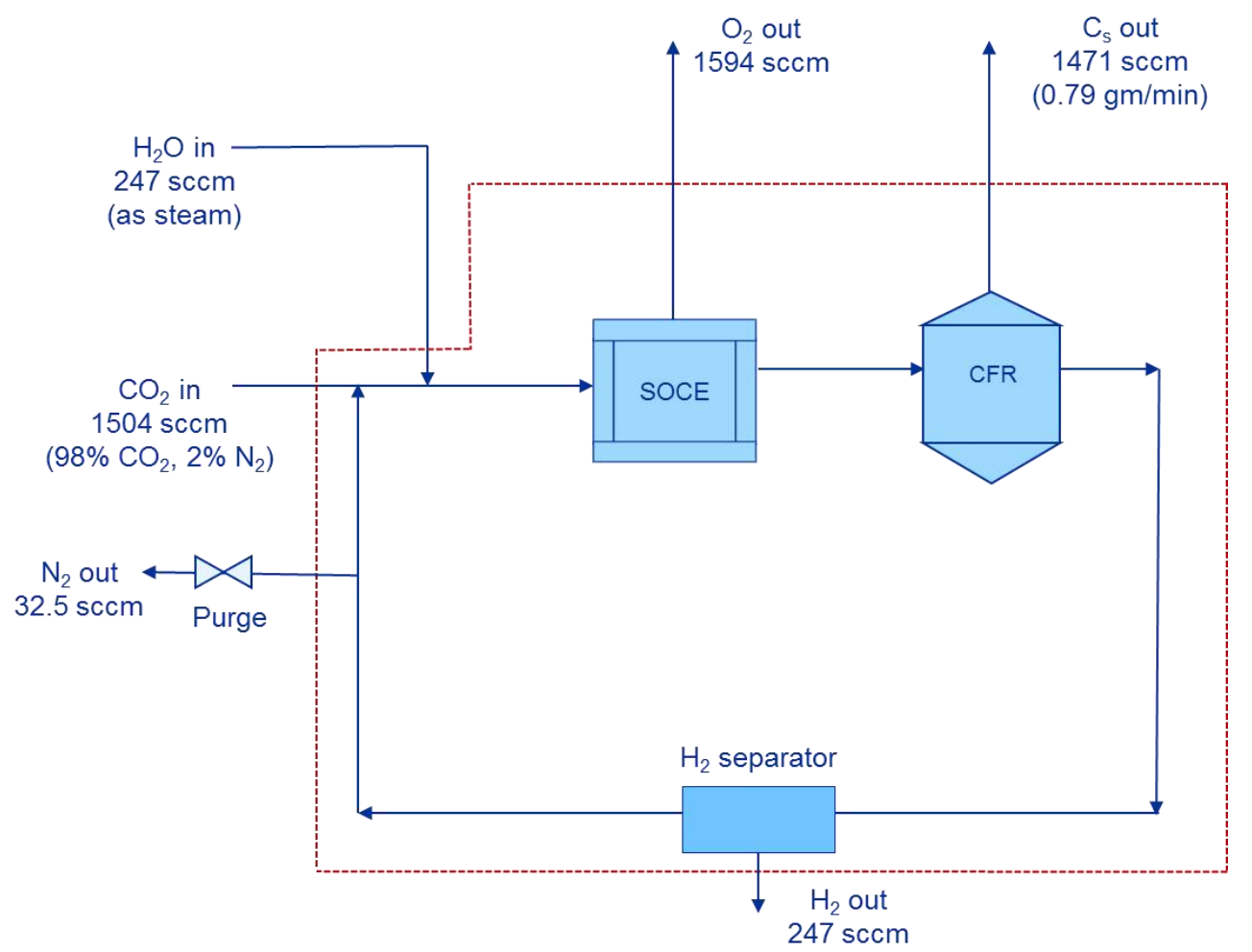

Figure 10. Overall mass (or mole) balance for a 4-CM SOCE-CFR system. The red dotted line indicates the portion of the system that would operate at sub-ambient pressure. The voumetric flow rates correspond to a mole balance as all gas reactions result in no increase or decrease in moles between reactants and products.

\begin{tabular}{|l|c|c|}
\hline \multicolumn{1}{|c|}{ Option } & $\begin{array}{c}\text { Oxygen Recovery } \\
\text { Rate }\end{array}$ & \multicolumn{1}{c|}{ Assumptions } \\
\hline $\begin{array}{l}\text { Theoretical System } \\
\text { Oxygen Recovery Rate }\end{array}$ & $100 \%$ & Pure $\mathrm{CO}_{2}$ and $\mathrm{H}_{2} \mathrm{O}$ feeds, $100 \% \mathrm{H}_{2}$ separation. No leakage. \\
\hline $\begin{array}{l}\mathrm{H}_{2} \text { and } \mathrm{N}_{2} \text { separation; CFR } \\
\text { regeneration purge }\end{array}$ & $99.86 \%$ & $\begin{array}{c}\mathrm{CO}_{2} \text { feed contains } 2 \% \mathrm{~N} 2 ; 100 \% \mathrm{~N}_{2} \text { and } \mathrm{H}_{2} \text { separation. CFR } \\
\text { regeneration every } 144 \text { hrs. }\end{array}$ \\
\hline $\begin{array}{l}\mathrm{H}_{2} \text { only separation, } \mathrm{N}_{2} \\
\text { purge }\end{array}$ & $89.70 \%$ & $20 \% \mathrm{~N}_{2}, 15 \% \mathrm{H}_{2}$ in purge stream (CFR exit concentration) \\
\hline $\begin{array}{l}\mathrm{N}_{2} \text { only separation, } \mathrm{H}_{2} \\
\text { purge }\end{array}$ & $69.50 \%$ & $20 \% \mathrm{~N}_{2}, 15 \% \mathrm{H}_{2}$ in purge stream (CFR exit concentration) \\
\hline $\begin{array}{l}\text { Purge (w/o any separation } \\
\text { components) }\end{array}$ & $69.50 \%$ & $20 \% \mathrm{~N}_{2}, 15 \% \mathrm{H}_{2}$ in purge stream (CFR exit concentration) \\
\hline
\end{tabular}

Table 1. Oxygen recovery rate projections. Estimates take into account losses in oxygen containing gases during carbon removal and several options for removing nitrogen and hydrogen gas build-up. Highlighted option corresponds to concept shown in Figure 10.

\section{B. Projected Oxygen Recovery Rate for SOCE-CFR system.}

The oxygen recovery rate was estimated for the SOCE-CFR system and is shown in Table 1 for various scenarios. This table highlights several options based on assumptions for the removal of $\mathrm{H}_{2}, \mathrm{~N}_{2}$, and CFR 
regeneration/carbon removal. Removing the $\mathrm{N}_{2}$ and $\mathrm{H}_{2}$ effluents, and the allowed gas concentrations in the purge stream strongly contribute to oxygen recovery. The " $\mathrm{H}_{2}$ only separation, $\mathrm{N}_{2}$ purge" option, highlighted in gray in Table 1, matches the assumptions for our conceptual SOCE-CFR design presented in the previous section and highlighted in Figure 10. $\mathrm{H}_{2}$ was found to be the "limiting" gas in these calculations, i.e. it most influences the oxygen recovery rate if purging, as opposed to separation, is the removal method. This due to the higher $\mathrm{H}_{2}$ generation rate, compared to the $\mathrm{N}_{2}$ entering the system via leakage and as a contaminant in the $\mathrm{CO}_{2}$ feed stream. But $\mathrm{N}_{2}$ can also be the limiting gas depending on changes in these assumptions, in particular it is dependent on: (1) $\mathrm{N}_{2}$ in the $\mathrm{CO}_{2}$ feed concentration, (2) assumed $\mathrm{N}_{2}$ leakage rate, and (3) $\mathrm{N}_{2}$ concentration in SOCE-CFR recycle (and as result purge) stream. Additionally, this analysis assumed no $\mathrm{CH}_{4}$ accumulation as the concentration of $\mathrm{CH}_{4}$ limited by thermodynamics; also, the analysis neglected the carbon and $\mathrm{H}_{2}$ that would also be removed in the purge stream.

\begin{tabular}{|c|c|c|c|c|}
\hline Component & Mass (kg) & $\begin{array}{l}\text { Volume } \\
\text { (liters) }\end{array}$ & $\begin{array}{l}\text { Power } \\
\text { (W) }\end{array}$ & Heat Loss \\
\hline SOCE (4 1-CM units) & 48.0 & 104 & 1424 & 588 \\
\hline CFR (4 1-CM units) & 30.0 & 92 & 140 & 320 \\
\hline \multicolumn{5}{|l|}{ CFR regeneration system } \\
\hline Preheater & 0.08 & - & - & - \\
\hline Valves (V1 and V2) & 2.64 & 1.28 & - & - \\
\hline Valves (V3 and V4) & 1.44 & 2.8 & - & - \\
\hline Motor & 1.6 & 0.59 & - & - \\
\hline Vacuum & 4.5 & 21.6 & 0.4 & 0.4 \\
\hline Hydrogen separator & 0.5 & 1.0 & - & - \\
\hline \multicolumn{5}{|l|}{ Water injection system } \\
\hline Accumulator & 1.00 & 16.60 & - & - \\
\hline Metering pump & 0.45 & 0.31 & 10 & 10 \\
\hline Deionizing bed & 0.30 & 0.10 & 0 & \\
\hline Vaporizer & 0.50 & 0.50 & - & - \\
\hline $\begin{array}{l}\text { Avionics (Process } \\
\text { controller) }\end{array}$ & 1.04 & 1.90 & 13 & 13 \\
\hline Blower & 1.00 & 1.20 & 20 & 20 \\
\hline Structure, tubing, sensors & 18.6 & - & - & - \\
\hline Totals & 112 & 245 & 1607 & 951 \\
\hline
\end{tabular}

Table 2. Mass, volume, power, cooling resources for a 4-CM SOCE-CFR system. Estimates based on SOCE and CFR scaled to 1-CM units and Balance-of-Plant components from commercial off the shelf sources (ref. 9).

\section{4-CM SOCE-CFR system mass, volume, power, and required cooling projections.}

Based on the SOCE-CFR mature hardware conceptual design discussed in the previous sections, mass, volume, power, and cooling values were rolled up into a 4-CM system, along with integrated system components. Table 2 provides this overall summary of these data projections. The remainder of the Balance-of-Plant (BOP) component estimates were based on commercial-off-the-shelf (COTS) if at all possible. Some component data were derived from COTS units that have actually flown on ISS as components of flight experiments, but it should be noted that ISS flight experiment hardware are typically Class D payloads and may not meet reliability and other requirement for ISS critical hardware, such as in life support systems. It should be noted that a missing component not addressed in this summary is the hydrogen separator; in this initial study, a hydrogen separator technology compatible with the low pressure and recycle gases (i.e. CO) was not identified. Finally, a $20 \%$ mass factor was applied to the 
component system mass to roughly approximate the structure, tubing, sensors, and other miscellaneous hardware necessary in the integrated system.

\section{Conclusion}

The results of a initial development to develop a two-stage carbon dioxide reduction sytem for oxygen recovery for life support was presented. The SOCE development achieved a new Pt-GDC cathode cell that is oxidation tolerant for this application and exhibited low degradation over 1200 hrs of durability testing. Significant strides were made in sealing and 3-cell stack fabrication of the SOCE, but additional development effort is needed to solve stack integrity problems. The CFR development achieved the key targets for resupply mass less than 1-kg/CM/year and operation up to 100+ hours before requiring regeneration and solid carbon removal.

A preliminary design for a flight SOCE-CFR system was developed and data projections show a system mass of $112 \mathrm{~kg}$ and power requirements of $1.6 \mathrm{~kW}$. Data projections for this SOCE-CFR system concept show a near $90 \%$ oxygen recovery rate, accounting for purge requirements, leakage, and CFR carbon removal.

Finally, we should like to note that both the SOCE and CFR technologies have potential applications in other NASA missions. The SOCE technology is an enabling in-situ resource utilization (ISRU) technology for oxygen recovery/generation from the Mars atmosphere, applicable to either crewed missions or robotic Mars sample return missions. In addition to the aerospace-specific needs of these two technologies, there are potential terrestrial applications, including air revitalization systems for naval submarines. The CFR technology also has terrestrial applications for the manufacturing of carbon nanomaterial-based products. Finally, these technologies have possible green energy applications for atmospheric $\mathrm{CO}_{2}$ mitigation, i.e. providing an alternative to $\mathrm{CO}_{2}$ sequestration by either producing a useful chemical feedstock (syngas) for synthetic fuels, ${ }^{13}$ or carbon fixing.

\section{Acknowledgments}

The authors would like to thank the Space Technology Mission Directorate (STMD) Game-Changing Development (GCD) Program for supporting this work. The authors would also like to thank Dan Barta (NASA JSC), Koorosh Araghi (NASA JSC), and Morgan Abney (NASA MSFC) for their guidance and many useful suggestions during the Phase I effort.

\section{References}

${ }^{1}$ Wheeler Jr, R.R., Hadley, N.M., Dahl, R.W., Abney, M.B., Greenwood, Z., Miller, L. and Medlen, A., "Advanced Plasma Pyrolysis Assembly (PPA) Reactor and Process Development," 42nd International Conference on Environmental Systems, July 2012.

${ }^{2}$ Wheeler, R.R., Hadley, N.M., Wambolt, S.R. and Abney, M.B., "Third Generation Advanced PPA Development”,44th International Conference on Environmental Systems, July 2014.

${ }^{3}$ Stoots, C. M., Hartvigsen, J. J., O’Brien. J. E., and Herring, J. S., "Syngas Production via High-Temperature Co-electrolysis of Steam and Carbon Dioxide," Fuel Cell Sci. Technol. 6(1), 011014, 2008.

${ }^{4}$ Wilson, R. B., "Fundamental Investigation of the Bosch Reaction," Master's Thesis, Dept. of Chemical Engineering, Massachusetts Institute of Technology, Cambridge, MA, 1971.

${ }^{5}$ Green, R. D., Liu, C. C., Adler, S. B., "Carbon dioxide reduction on gadolinia-doped ceria cathodes," Solid State Ionics, 179, 2008, pp. 647-660.

${ }^{6}$ Graves, C., Chatzichristodoulou, C., Mogensen, M., "Kinetics of $\mathrm{CO} / \mathrm{CO} 2$ and $\mathrm{H} 2 / \mathrm{H} 2 \mathrm{O}$ reactions at Ni-based and ceriabased solid-oxide-cell electrodes", Faraday Discuss., 2015, 182, pp. 75-95.

${ }^{7}$ Kim-Lohsoontorn, P., and Bae, J., "Electrochemical performance of solid oxide electrolysis cell electrodes under hightemperature co-electrolysis of steam and carbon dioxide," J. Power Sources, 196, 2011, pp. 7161-7168.

${ }^{8}$ Shelef, M., Graham, J. W., McCabe, R. W., "Ceria and other oxygen storage components in automotive catalysts," In: Trovarelli A (Ed.), Catalysis by Ceria and Related Materials, vol. 2, Imperial College Press, London, 2002, pp. 343-365.

${ }^{9}$ Green, R.D., Matter, P. H., Farmer, S., Beachy, M., Setlock, J., Gaydos, J., and Holt, C., "Phase I Final Report for the SpaceCraft Oxygen Recovery (SCOR) Project: A Combined Solid Oxide Co-Electrolyzer and Carbon Formation Reactor System for Spacecraft Life Support Oxygen Regeneration", NASA TM (to be published).

${ }^{10}$ Cable, T. L., Setlock, J. A., Farmer, S. C., and Eckel, A. J., "Regenerative Performance of the NASA Symmetrical Solid Oxide Fuel Cell Design,” Int. J. Appl. Ceram. Tech., 8(1), 2011, pp. 1-12.

${ }^{11}$ Holmes, R.F., E.E. Keller, and C.D. King, "A Carbon Dioxide Reduction Unit Using Bosch Reaction and Expendable Catalyst Cartridges," NASA-CR-143959, Contract NAS1-8217, July 1975.

${ }^{12}$ Anderson, M. S., Ewert, M. K., Keener, J. F., and Wagne, S. A., "Life Support Baseline Values and Assumptions Document," NASA/TP-2015-218570, March 2015. 
${ }^{13}$ Graves, C., Ebbesen, S. D., Mogensen, M., and Lackner, K. S., "Sustainable hydrocarbon fuels by recycling $\mathrm{CO}_{2}$ and $\mathrm{H}_{2} \mathrm{O}$ with renewable or nuclear energy,” Renew. Sust. Energ. Rev., 15(1), 2011, pp. 75-95. 